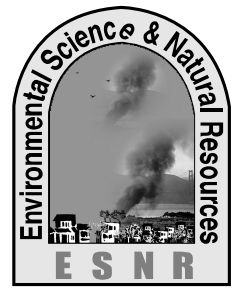

J. Environ. Sci. \& Natural Resources, 5(1): 273- 282, 2012

ISSN 1999-7361

\title{
Effect of Organic and Inorganic Sources and Doses of Nitrogen Fertilizer on the Yield of Boro Rice
}

\author{
M. A. Alim \\ Department of Agronomy and Agricultural Extension, University of Rajshahi, Bangladesh
}

\begin{abstract}
The experiment was conducted to study the effect of different sources and doses of nitrogen application on the yield formation of boro rice. Two indica modern boro rice varieties (BRRI dhan28 and BRRI dhan36) and 21 nitrogen fertilizer combinations were used in the experiment. The experiment was laid out in split- plot design with three replications by assigning varieties in the main plots and nitrogen fertilizers in the sub-plots. The unit plot size was $4 \mathrm{~m} \times 2 \mathrm{~m}$. Yield and yield contributing characters were measured. Among the two varieties BRRI dhan 28 produced higher grain and straw yield. Grain and straw yields were increased with the increase of nitrogen rate up to $120 \mathrm{~kg} \mathrm{ha}^{-1}$ at all the sources In general, organic manures alone could not produce higher grain yield but the combination of organic and inorganic fertilizers produced higher yield. The application of $60 \mathrm{~kg} \mathrm{~N} \mathrm{ha}^{-1}$ as urea with $60 \mathrm{~kg} \mathrm{~N} \mathrm{ha}^{-1}$ as mustard oil cake (MOC) produced maximum grain and straw yield which was statistically similar to the yield of $50 \mathrm{~kg} \mathrm{~N} \mathrm{ha}{ }^{-1}$ as urea with $50 \mathrm{~kg} \mathrm{~N} \mathrm{ha}^{-1}$ as MOC. The lowest values were found in control nitrogen application. The results suggest that replacement of $50 \%$ urea $\mathrm{N}$ by MOC was the best source of nitrogen considering higher yield of boro rice. Therefore, fertilization of BRRI dhan28 and BRRI dhan36 varieties of rice with $60 \mathrm{~kg} \mathrm{~N} \mathrm{ha}^{-1}$ as urea and $60 \mathrm{~kg} \mathrm{~N} \mathrm{ha}^{-1}$ as MOC or $50 \mathrm{~kg} \mathrm{~N}^{-}$ ${ }^{1}$ as urea with $50 \mathrm{~kg} \mathrm{~N} \mathrm{ha}^{-1}$ as MOC was found to be the best nitrogen rate among all the treatment combinations in respect of grain and straw yields.
\end{abstract}

Keywords: Cow dung, Mustard oil cake, Yield, Nitrogen, Urea, Boro rice

\section{Introduction}

Rice (Oryza sativa) is the staple food for nearly half of the world's population as well as for 148.10 million people (AIS, 2008) of Bangladesh. Rice plays absolutely dominant role in Bangladesh agriculture as it covers 77.96 percent of total cropped area (AIS, 2007). It contributes $14.6 \%$ to the national GDP (BBS, 2004). The yield level of rice is very low $\left(2.43 \mathrm{t} \mathrm{ha}^{-1}\right.$, BBS, 2004) compared to other rice growing countries like South Korea and Japan where the average yield is 7.00 and $6.22 \mathrm{t} \mathrm{ha}^{-1}$, respectively (FAO, 1999). It has already been reported that decreasing organic matter in farm soils has caused significant yield reductions (Islam, 1989). The low yield of boro rice is due to several factors. Sources of $\mathrm{N}$ fertilizer are an important factor for obtaining higher yields.

It is well known that inorganic fertilizers supply only nutrients in soil but organic manure supplies nutrients and at the same time improves soil quality. The longterm impact of chemical fertilizers on soils and environment is harmful. Use of unbalanced nutrients in the soils may be harmful in the long run causing soils an unproductive one. It is true that sustainable production of crops cannot be maintained by using only chemical fertilizers and similarly it is not possible to obtain higher crop yield by using organic manure alone (Bair, 1990). Proper identification and management of soil fertility problems are prerequisite for boosting crop production and sustaining higher yields over a long period of time.
So use of organic manure in integration with inorganic fertilizers is very important in improving soil fertility and crop productivity. But sufficient information is not available about appropriate sources of organic manure and proper combination of organic and inorganic fertilizers suitable for rice based cropping system in Bangladesh to increase yield and improve soil fertility. Among the available organic sources of $\mathrm{N}$, cow dung and mustard oil cake are rich in $\mathrm{N}$ content. Cow dung is the commonly practiced organic manure for crop cultivation in Bangladesh. It is an important source for supplying nutrients for crop production and is recognized as a substitute for inorganic fertilizers (Sharma and Mitra, 1991). The long-term research of BRRI reveals that addition of cow dung at the rate of $5 \mathrm{t} \mathrm{ha}^{-1}$ improved the rice productivity as well as prevented the soil resources from degradation (Bhuiyan, 1994). Moreover, use of cow dung not only acts as a source of $\mathrm{N}$ and other nutrients but also increase the efficiency of applied nitrogen (Sarvanan et al., 1987).

Nitrogen is the key element for crop production and it is required in larger amount compared with other fertilizers but it is a costly item when it is derived from artificial sources. But adding organic material from easy and available sources can minimize the cost. De Datta et al. (1981) reported that the low fertility of rice soils and a limited supply of inorganic fertilizers are the major constraints to increase rice yield in South and Southeast Asia. Improper use of 
fertilizers may reduce the yield of rice in spite of increasing the nitrogen rates. Efficient fertilizer management gave higher yield of crops and reduced fertilizer cost. (Hossain and Islam,1986). But the amount of fertilizer is in appropriate in most cases due to lack of proper knowledge and over $97 \%$ of the farmers do not follow the recommended dose of fertilizer (Hossain et al. 1981). It is essential to find out the optimum rate of nitrogen application for efficient use of this element by the plants for better yield.

Effort is needed to formulate an input package with a combination of organic and inorganic fertilizers. So that it will be technically effective and feasible, economically viable, socially and environmentally acceptable. But the research work for the use of cow dung and mustard oil cake as a source of $\mathrm{N}$ is rare. Therefore, the present study was conducted to evaluate the effect of organic and synthetic nitrogen and their combination on productivity of boro rice and the replacement of chemical fertilizer by organic fertilizer.

\section{Materials and Methods}

The experiment was conducted at the Agronomy Field Laboratory, University of Rajshahi, Bangladesh during December 2004 to May 2005. The experimental soil contained $7.58 \mathrm{pH}, 1.45 \%$ organic carbon, $0.14 \%$ total nitrogen, $7.25 \mathrm{ppm}$ available $\mathrm{P}$, $176 \mathrm{ppm}$ available $\mathrm{K}$ and $21 \mathrm{ppm}$ available $\mathrm{S}$. The experiment consisted of two modern rice varieties (BRRI dhan28 and BRRI dhan36) and 21 fertilizer combinations viz., $\mathrm{T}_{1}$ (control), $\mathrm{T}_{2}\left(60 \mathrm{~kg} \mathrm{~N} \mathrm{ha}^{-1}\right.$ as urea), $\mathrm{T}_{3}\left(60 \mathrm{~kg} \mathrm{~N} \mathrm{ha}^{-1}\right.$ as cow dung), $\mathrm{T}_{4}\left\{60 \mathrm{~kg} \mathrm{~N} \mathrm{ha}^{-1}\right.$ as mustard oil cake (MOC) $\}, \mathrm{T}_{5}\left(30 \mathrm{~kg} \mathrm{~N} \mathrm{ha}^{-1}\right.$ as urea $+30 \mathrm{~kg} \mathrm{~N} \mathrm{ha}^{-1}$ as cow dung), $\mathrm{T}_{6}\left(30 \mathrm{~kg} \mathrm{~N} \mathrm{ha}^{-1}\right.$ as urea $+30 \mathrm{~kg} \mathrm{~N} \mathrm{ha}^{-1}$ as MOC), $\mathrm{T}_{7}\left(80 \mathrm{~kg} \mathrm{~N} \mathrm{ha}^{-1}\right.$ as urea), $\mathrm{T}_{8}$ (80 kg N ha ${ }^{-1}$ as cow dung), $\mathrm{T}_{9}\left(80 \mathrm{~kg} \mathrm{~N} \mathrm{ha}^{-1}\right.$ as MOC), $\mathrm{T}_{10}\left(40 \mathrm{~kg} \mathrm{~N}^{-1}\right.$ as urea $+40 \mathrm{~kg} \mathrm{~N} \mathrm{ha}^{-1}$ as cow dung), $\mathrm{T}_{11}\left(40{\mathrm{~kg} \mathrm{~N} h{ }^{-1}}^{-}\right.$as urea $+40 \mathrm{~kg} \mathrm{~N} \mathrm{ha}^{-1}$ as MOC), $T_{12}\left(100 \mathrm{~kg} \mathrm{~N} \mathrm{ha}^{-1}\right.$ as urea), $\mathrm{T}_{13}\left(100 \mathrm{~kg} \mathrm{~N}^{-1}\right.$ as cow dung), $\mathrm{T}_{14}\left(100 \mathrm{~kg} \mathrm{~N} \mathrm{ha}^{-1}\right.$ as MOC), $\mathrm{T}_{15}(50 \mathrm{~kg}$ $\mathrm{N} \mathrm{ha}^{-1}$ as urea $+50 \mathrm{~kg} \mathrm{~N} \mathrm{ha}^{-1}$ as cow dung), $\mathrm{T}_{16}(50 \mathrm{~kg}$ $\mathrm{N} \mathrm{ha}^{-1}$ as urea $+50 \mathrm{~kg} \mathrm{~N}^{-1}{ }^{-1}$ as MOC $), \mathrm{T}_{17}(120 \mathrm{~kg} \mathrm{~N}$ $\mathrm{ha}^{-1}$ as urea), $\mathrm{T}_{18}\left(120 \mathrm{~kg} \mathrm{~N} \mathrm{ha}^{-1}\right.$ as cow dung), $\mathrm{T}_{19}$ (120 kg N ha ${ }^{-1}$ as MOC), $\mathrm{T}_{20}\left(60 \mathrm{~kg} \mathrm{~N} \mathrm{ha}^{-1}\right.$ as urea +
$60 \mathrm{~kg} \mathrm{~N} \mathrm{ha}^{-1}$ as cow dung), $\mathrm{T}_{21}\left(60 \mathrm{~kg} \mathrm{~N} \mathrm{ha}^{-1}\right.$ as urea + $60 \mathrm{~kg} \mathrm{~N} \mathrm{ha}^{-1}$ as MOC). The experiment was laid out in split- plot design with three replications by assigning varieties in the main plots and nitrogen fertilizers in the sub-plots. The unit plot size was $4 \mathrm{~m}$ $\times 2 \mathrm{~m}$. The land was fertilized with $60 \mathrm{~kg} \mathrm{P}_{2} \mathrm{O}_{5}, 50 \mathrm{Kg}$ $\mathrm{K}_{2} \mathrm{O}, 10 \mathrm{Kg} \mathrm{S}$ and $4 \mathrm{Kg} \mathrm{Zn} \mathrm{ha}^{-1}$ as basal dose in the form of triple super phosphate, muriate of potash, gypsum and $\mathrm{ZnO}$, respectively by subtracting the amount coming from cow dung or mustard oil cake. Treatment wise required amount of cow dung and mustard oil cake were incorporated thoroughly with soil before 7 days of transplanting. Treatment wise nitrogen as urea, cow dung and mustard oil cake was applied in three equal splits at 15,30 and 50 days after transplanting (DAT). The control plots received no nitrogenous fertilizer. 35 days-old seedlings were transplanted by hand at $20 \mathrm{~cm} \times 15 \mathrm{~cm}$ spacing on 17 January 2005. All intercultural operations were performed as and when necessary. The date of harvest was determined, when $90 \%$ of the grains became golden yellow color. The harvested crop of each plot was bundled separately, tagged properly and brought to the clean threshing floor. The bundles were dried on open sunshine, threshed and then seeds were cleaned. The seed and straw weights for each plot were recorded after proper sun drying.

Five hills (Except the two border rows hill and central $1 \mathrm{~m}^{2}$ area) were selected randomly from each plot prior to harvest for collecting data on crop characters. The grain, straw, biological yields and harvest index were recorded from one square meter area of each plot at harvest. The data were analyzed statistically and adjudged the mean differences by Duncan`s New Multiple Range Test (DMRT) (Gomez and Gomez, 1984) with the help of computer package MSTAT-C.

\section{Results and Discussion}

Results showed that most of the yield components i.e. bearing tillers hill ${ }^{-1}$, panicle length, number of grains panicle $^{-1}, 1000$ - grain weight, grain yield, straw yield and biological yield studied were significantly influenced due to varieties. All the yield components studied varied significantly due to the application of different sources and doses of nitrogen. 
Table 1. Effect of variety on yield and yield contributing characters of boro rice

\begin{tabular}{|c|c|c|c|c|c|c|c|c|c|c|}
\hline Treatment & $\begin{array}{c}\text { Plant } \\
\text { height } \\
(\mathrm{cm})\end{array}$ & $\begin{array}{c}\text { Bearing } \\
\text { tillers } \\
\text { (no.) }\end{array}$ & $\begin{array}{c}\text { Non- } \\
\text { bearing } \\
\text { tillers } \\
\text { (no.) }\end{array}$ & $\begin{array}{l}\text { Length } \\
\text { of } \\
\text { panicle } \\
(\mathrm{cm})\end{array}$ & $\begin{array}{c}\text { Grains } \\
\text { panicle }^{-1} \\
\text { (no. })^{-1}\end{array}$ & $\begin{array}{c}\text { Sterile } \\
\text { spikelets } \\
\text { panicle }^{-1} \\
(\text { no. })\end{array}$ & $\begin{array}{c}\text { Weight } \\
\text { of } 1000 \\
\text { grains } \\
\text { (g) }\end{array}$ & $\begin{array}{c}\text { Grain } \\
\text { yield } \\
\left(\mathbf{t ~ h a}^{-1}\right)\end{array}$ & $\begin{array}{c}\text { Straw } \\
\text { yield } \\
\left.\text { ha }^{-1}\right)\end{array}(\mathbf{t}$ & $\begin{array}{c}\text { Harvest } \\
\text { index } \\
(\%)\end{array}$ \\
\hline $\begin{array}{l}\text { BRRI } \\
\left.\text { dhan28( } V_{1}\right)\end{array}$ & 92.22 & $9.28 \mathrm{a}$ & $3.51 \mathrm{a}$ & $22.84 \mathrm{a}$ & $115.00 \mathrm{a}$ & $12.35 b$ & 22.99 & $4.62 \mathrm{a}$ & $5.25 \mathrm{a}$ & 12.21 \\
\hline $\begin{array}{l}\text { BRRI } \\
\text { dhan36 }\left(V_{2}\right)\end{array}$ & 88.88 & $8.36 b$ & $3.03 b$ & $22.03 b$ & $110.00 \mathrm{~b}$ & $14.48 \mathrm{a}$ & 23.23 & $4.34 \mathrm{~b}$ & $4.93 \mathrm{~b}$ & 14.34 \\
\hline $\mathrm{CV}(\%)$ & 10.55 & 5.46 & 20.24 & 6.86 & 5.31 & 6.60 & 5.88 & 7.28 & 7.58 & 4.81 \\
\hline $\begin{array}{l}\text { Level of } \\
\text { Significance }\end{array}$ & NS & 0.01 & 0.05 & 0.05 & 0.05 & 0.05 & NS & 0.01 & 0.05 & NS \\
\hline
\end{tabular}

In a column the figures bearing same letter (s) or without letter are identical and those having dissimilar letters differed significantly as per DMRT. $\mathrm{V}_{1}=$ BRRIdhan 28, $\mathrm{V}_{2}=$ BRRIdhan 28 
Table 2. Effect of nitrogen sources and doses on yield and yield contributing characters of boro rice

\begin{tabular}{|c|c|c|c|c|c|c|c|c|c|c|}
\hline Treatment & $\begin{array}{c}\text { Plant } \\
\text { height } \\
(\mathbf{c m})\end{array}$ & $\begin{array}{c}\text { Bearing } \\
\text { tillers } \\
\text { (no) }\end{array}$ & $\begin{array}{c}\text { Non- } \\
\text { bearing } \\
\text { tillers } \\
\text { (no) }\end{array}$ & $\begin{array}{l}\text { Length of } \\
\text { panicle } \\
\text { (cm) }\end{array}$ & $\begin{array}{l}\text { Grains } \\
\text { panicle }^{-1} \\
\text { (no) }\end{array}$ & $\begin{array}{c}\text { Sterile } \\
\text { spikelets } \\
\text { panicle }^{-} \\
{ }_{1} \text { (no) }\end{array}$ & $\begin{array}{l}\text { Weight of } \\
1000 \\
\text { grains (g) }\end{array}$ & $\begin{array}{c}\text { Grain } \\
\text { yield }(t \\
\left.\text { ha }^{-1}\right)\end{array}$ & $\begin{array}{c}\text { Straw } \\
\text { yield }(t \\
\left.\text { ha }^{-1}\right)\end{array}$ & $\begin{array}{c}\text { Harvest } \\
\text { index }(\% \\
)\end{array}$ \\
\hline $\mathrm{T}_{1}$ & $81.04 \mathrm{gh}$ & $5.45 \mathrm{k}$ & $2.33 \mathrm{~g}$ & $20.47 \mathrm{j}$ & $86.11 \mathrm{ef}$ & $13.90 \mathrm{bc}$ & $22.37 \mathrm{ef}$ & $2.51 \mathrm{i}$ & $3.48 \mathrm{~h}$ & $41.90 \mathrm{~d}$ \\
\hline $\mathrm{T}_{2}$ & $83.22 \mathrm{e}-\mathrm{h}$ & $7.40 \mathrm{~h}$ & $2.94 \mathrm{c}-\mathrm{g}$ & 21.47fghij & $100.78 \mathrm{~h}-\mathrm{k}$ & $11.67 \mathrm{de}$ & $22.08 \mathrm{f}$ & $3.42 \mathrm{~h}$ & $4.18 \mathrm{~g}$ & $45.00 \mathrm{~cd}$ \\
\hline$T_{3}$ & $86.18 \mathrm{~d}-\mathrm{h}$ & $6.56 \mathrm{j}$ & $2.72 \mathrm{~d}-\mathrm{g}$ & $20.58 \mathrm{ij}$ & $100.71 \mathrm{i}-\mathrm{k}$ & $13.31 \mathrm{c}$ & $22.56 \mathrm{~d}-\mathrm{f}$ & $3.37 \mathrm{~h}$ & $4.02 \mathrm{~g}$ & $45.60 \mathrm{~cd}$ \\
\hline $\mathrm{T}_{4}$ & $82.58 \mathrm{f}-\mathrm{h}$ & $8.41 \mathrm{f}$ & $2.37 \mathrm{fg}$ & $22.43 c-h$ & $109.86 \mathrm{e}-\mathrm{h}$ & $10.17 \mathrm{fg}$ & $23.14 \mathrm{a}-\mathrm{f}$ & $3.63 \mathrm{~h}$ & $4.04 \mathrm{~g}$ & $47.33 \mathrm{a}-\mathrm{c}$ \\
\hline $\mathrm{T}_{5}$ & $85.80 \mathrm{~d}-\mathrm{h}$ & $7.00 \mathrm{i}$ & $2.56 \mathrm{e}-\mathrm{g}$ & $20.90 \mathrm{~h}-\mathrm{j}$ & 94.70j-1 & $11.39 \mathrm{ef}$ & $22.44 \mathrm{ef}$ & $3.45 \mathrm{~h}$ & $4.12 \mathrm{~g}$ & $45.57 \mathrm{~b}-\mathrm{d}$ \\
\hline $\mathrm{T}_{6}$ & 83.89ef-h & $8.41 \mathrm{f}$ & $2.48 \mathrm{e}-\mathrm{g}$ & $21.87 \mathrm{e}-\mathrm{j}$ & $102.20 \mathrm{ef}$ & $10.29 \mathrm{fg}$ & $22.65 \mathrm{def}$ & $3.59 \mathrm{~h}$ & $4.08 \mathrm{~g}$ & $46.81 \mathrm{bc}$ \\
\hline $\mathrm{T}_{7}$ & $85.54 d-h$ & 7.13hi & $3.02 \mathrm{c}-\mathrm{g}$ & $21.28 \mathrm{~g}-\mathrm{j}$ & $101.11 \mathrm{~g}-\mathrm{i}$ & $11.33 \mathrm{ef}$ & $22.65 d-f$ & $4.13 \mathrm{~g}$ & $4.83 \mathrm{f}$ & $46.09 \mathrm{bc}$ \\
\hline $\mathrm{T}_{8}$ & $88.25 \mathrm{c}-\mathrm{g}$ & $5.59 \mathrm{k}$ & $3.29 \mathrm{c}-\mathrm{g}$ & $21.28 \mathrm{gh}-\mathrm{j}$ & 91.381 & $12.92 \mathrm{~cd}$ & $22.83 \mathrm{~d}-\mathrm{f}$ & $4.27 \mathrm{fg}$ & 4.92ef & $46.46 \mathrm{bc}$ \\
\hline $\mathrm{T}_{9}$ & $84.19 \mathrm{~b}-\mathrm{f}$ & $9.51 \mathrm{~d}$ & $3.15 c-g$ & $22.62 \mathrm{c}-\mathrm{g}$ & $110.16 \mathrm{e}-\mathrm{g}$ & $9.10 \mathrm{~g}$ & $22.92 \mathrm{~cd}-\mathrm{f}$ & $4.72 \mathrm{~b}-\mathrm{e}$ & 5.13def & $47.92 \mathrm{a}-\mathrm{c}$ \\
\hline $\mathrm{T}_{10}$ & $87.65 \mathrm{c}-\mathrm{g}$ & $7.40 \mathrm{~h}$ & $2.74 \mathrm{~d}-\mathrm{g}$ & $22.22 \mathrm{~d}-\mathrm{i}$ & $106.11 \mathrm{f}-\mathrm{i}$ & $11.37 \mathrm{ef}$ & $22.36-f$ & $4.41 \mathrm{efg}$ & $4.95 \mathrm{ef}$ & $47.12 \mathrm{a}-\mathrm{c}$ \\
\hline $\mathrm{T}_{11}$ & $86.91 \mathrm{~d}-\mathrm{h}$ & $8.89 \mathrm{e}$ & $3.11 \mathrm{c}-\mathrm{g}$ & $22.80 \mathrm{~b}-\mathrm{g}$ & $103.50 \mathrm{f}-\mathrm{j}$ & $10.80 \mathrm{ef}$ & $22.80 \mathrm{~d}-\mathrm{f}$ & $4.86 \mathrm{~b}-\mathrm{d}$ & $5.52 \mathrm{~cd}$ & $46.82 \mathrm{bc}$ \\
\hline $\mathrm{T}_{12}$ & $92.67 \mathrm{a}-\mathrm{d}$ & $9.51 \mathrm{~d}$ & $3.67 \mathrm{~b}-\mathrm{e}$ & $22.22 \mathrm{~d}-\mathrm{i}$ & $123.68 \mathrm{~cd}$ & $13.88 \mathrm{bc}$ & 23.33a-f & 4.60d-f & $5.26 \mathrm{~d}-\mathrm{f}$ & $46.65 \mathrm{bc}$ \\
\hline $\mathrm{T}_{13}$ & $79.58 \mathrm{~h}$ & $8.09 \mathrm{~g}$ & 4.58ab & $22.25 \mathrm{~d}-\mathrm{h}$ & $111.62 \mathrm{ef}$ & $14.63 \mathrm{ab}$ & $23.08 \mathrm{~b}-\mathrm{f}$ & $4.60 \mathrm{~d}-\mathrm{f}$ & $5.28 \mathrm{de}$ & $46.56 b c$ \\
\hline $\mathrm{T}_{14}$ & $90.49 \mathrm{~b}-\mathrm{e}$ & $10.43 \mathrm{c}$ & $3.35 \mathrm{c}-\mathrm{g}$ & $22.37 \mathrm{~d}-\mathrm{h}$ & 142.27a & $13.56 \mathrm{c}$ & 24.31ab & 5.52a-c & $5.92 \mathrm{a}-\mathrm{c}$ & 48.68a \\
\hline $\mathrm{T}_{15}$ & $88.82 \mathrm{c}-\mathrm{f}$ & $9.78 \mathrm{~d}$ & $3.55 b-f$ & $23.42 a-e$ & $131.05 \mathrm{bc}$ & $14.00 \mathrm{bc}$ & 23.20a-f & $5.04 b c$ & $5.89 \mathrm{bc}$ & $46.11 b c$ \\
\hline $\mathrm{T}_{16}$ & $95.02 \mathrm{a}-\mathrm{c}$ & $11.35 \mathrm{~b}$ & $3.32 \mathrm{c}-\mathrm{g}$ & $23.75 a-d$ & $125.47 \mathrm{~b}-\mathrm{d}$ & $13.73 b c$ & 23.48a-e & $5.75 a$ & 6.14ab & $48.36 \mathrm{ab}$ \\
\hline $\mathrm{T}_{17}$ & 98.75a & $10.43 \mathrm{c}$ & $3.99 a-c$ & $23.17 \mathrm{a}-\mathrm{e}$ & $118.17 \mathrm{de}$ & $14.09 \mathrm{bc}$ & $23.85 a-d$ & $4.71 \mathrm{c}-\mathrm{e}$ & $5.24 \mathrm{~d}-\mathrm{f}$ & $47.34 \mathrm{~b}$ \\
\hline $\mathrm{T}_{18}$ & $89.15 b-f$ & $9.76 \mathrm{~d}$ & 4.81a & $22.96 b-f$ & $93.72 \mathrm{kl}$ & $15.40 \mathrm{a}$ & $23.33 \mathrm{a}-\mathrm{f}$ & $4.69 \mathrm{c}-\mathrm{e}$ & $5.54 \mathrm{~cd}$ & $45.85 \mathrm{~b}-\mathrm{d}$ \\
\hline $\mathrm{T}_{19}$ & $96.56 \mathrm{ab}$ & $11.43 b$ & $3.60 \mathrm{~b}-\mathrm{e}$ & 24.68a & 134.05ab & $13.87 \mathrm{bc}$ & $24.50 \mathrm{a}$ & 5.60ab & 6.02ab & $48.19 \mathrm{ab}$ \\
\hline $\mathrm{T}_{20}$ & 94.91a-c & $10.47 \mathrm{c}$ & 3.82a-d & $24.08 \mathrm{a}-\mathrm{c}$ & $118.78 \mathrm{de}$ & 14.76ab & $23.26 \mathrm{a}-\mathrm{f}$ & $5.08 \mathrm{~b}$ & $5.89 \mathrm{bc}$ & $46.31 \mathrm{bc}$ \\
\hline $\mathrm{T}_{21}$ & 98.44a & $12.34 a$ & $3.39 \mathrm{c}-\mathrm{g}$ & 24.38ab & $\begin{array}{l}126.66 \mathrm{~b}- \\
\mathrm{d}\end{array}$ & $14.14 \mathrm{a}-\mathrm{c}$ & $24.23 \mathrm{a}-\mathrm{c}$ & 5.85a & $6.34 a$ & $47.99 b$ \\
\hline $\mathrm{CV}(\%)$ & 10.55 & 5.46 & 20.24 & 6.86 & 5.31 & 6.60 & 5.88 & 7.28 & 7.58 & 4.81 \\
\hline $\begin{array}{l}\text { Level of } \\
\text { Significanc }\end{array}$ & 0.05 & 0.05 & 0.05 & 0.05 & 0.05 & 0.05 & 0.05 & 0.05 & 0.05 & 0.05 \\
\hline
\end{tabular}

In a column the figures bearing same letter (s) or without letter are identical and those having dissimilar letters differed significantly as per DMRT.

$\mathrm{T}_{1}=$ Control, $_{1} \mathrm{~T}_{2}=60 \mathrm{~kg} \mathrm{Urea} \mathrm{N} \mathrm{ha}^{-1}, \mathrm{~T}_{3}=60 \mathrm{~kg} \mathrm{CD} \mathrm{N} \mathrm{ha}^{-1}, \mathrm{~T}_{4}=60 \mathrm{~kg} \mathrm{MOC} \mathrm{N} \mathrm{ha}^{-1}, \mathrm{~T}_{5}=30 \mathrm{~kg}_{\text {Urea N ha }}{ }^{-1}+30 \mathrm{~kg} \mathrm{CD} \mathrm{N} \mathrm{ha}^{-1}, \mathrm{~T}_{6}=30 \mathrm{~kg} \mathrm{Urea} \mathrm{N} \mathrm{ha}^{-1}+30 \mathrm{~kg} \mathrm{MOC} \mathrm{N} \mathrm{ha}^{-1}, \mathrm{~T}_{7}=80 \mathrm{~kg} \mathrm{Urea} \mathrm{N} \mathrm{ha}^{-1}, \mathrm{~T}_{8}=80$

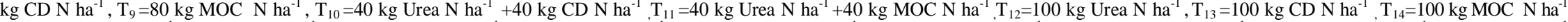
$\mathrm{T}_{15}=50 \mathrm{~kg}$ Urea $\mathrm{N} \mathrm{ha}^{-1}+50 \mathrm{~kg} \mathrm{CD} \mathrm{N} \mathrm{ha}^{-1}, \mathrm{~T}_{16}=50 \mathrm{~kg} \mathrm{Urea} \mathrm{N} \mathrm{ha}^{-1}+50 \mathrm{~kg} \mathrm{MOC} \mathrm{N} \mathrm{ha}^{-1}, \mathrm{~T}_{17}=120 \mathrm{~kg}$ Urea N ha ${ }^{-1}, \mathrm{~T}_{18}=120 \mathrm{~kg} \mathrm{CD} \mathrm{N}^{-1}, \mathrm{~T}_{19}=120 \mathrm{~kg}^{2} \mathrm{MOC} \mathrm{N}^{-1}, \mathrm{~T}_{20}=60 \mathrm{~kg} \mathrm{Urea} \mathrm{N}^{-1}+60 \mathrm{~kg} \mathrm{CD} \mathrm{N}^{-1}$,

$\mathrm{T}_{21}=60 \mathrm{~kg}$ Urea $\mathrm{N} \mathrm{ha}^{-1}+60 \mathrm{~kg} \mathrm{~N}^{-1} \mathrm{MOC}$ 
Table 3. Interaction effect of variety and nitrogen sources and doses on yield and yield contributing characters of boro rice

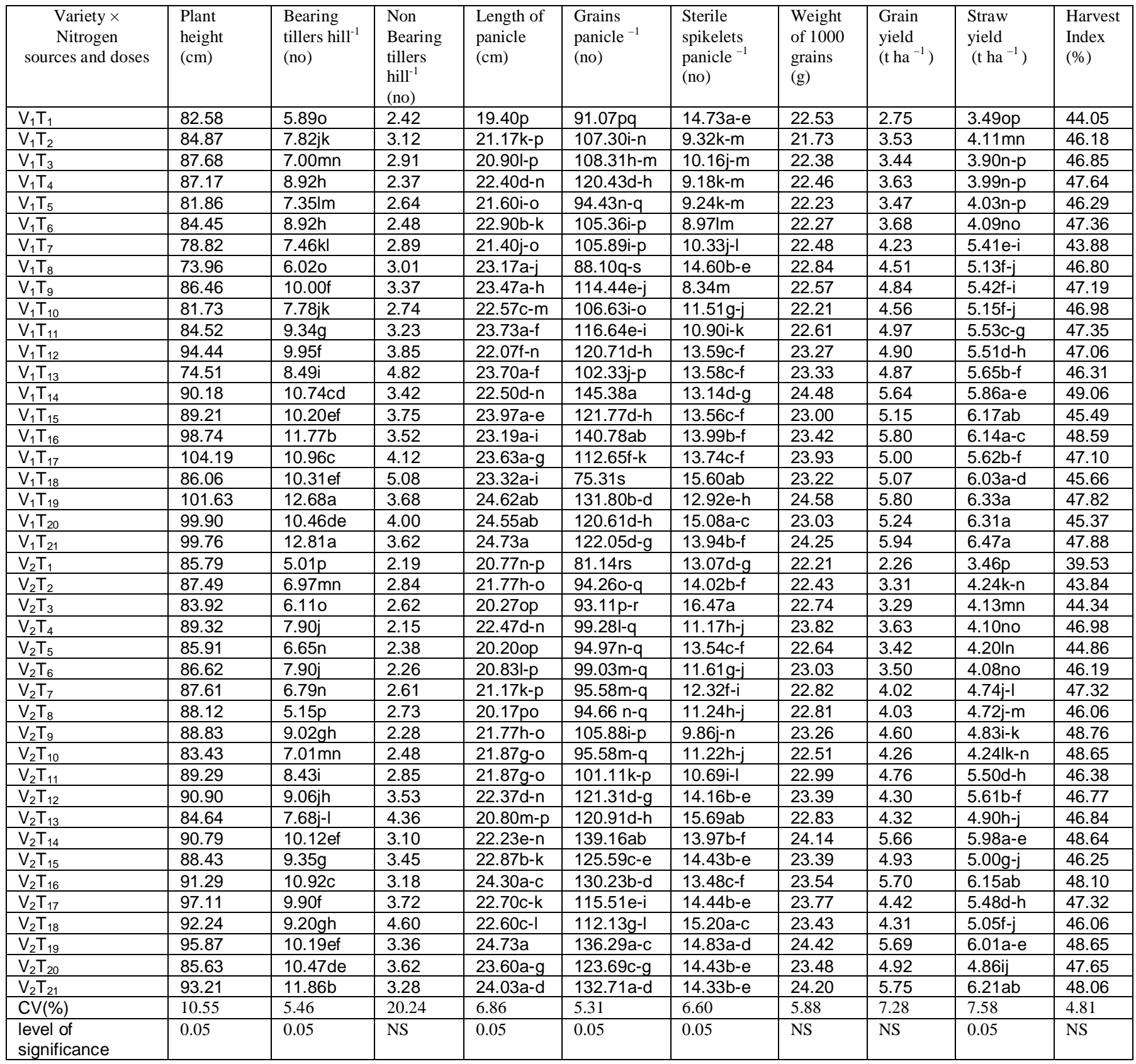

In a column the figures bearing same letter (s) or without letter are identical and those having dissimilar letters differed significantly as per DMRT.

$\mathrm{V}_{1}=$ BRRIdhan $28, \mathrm{~V}_{2}=$ BRRIdhan 28

$\mathrm{T}_{1}=$ Control, $\mathrm{T}_{2}=60 \mathrm{~kg}$ Urea $\mathrm{N} \mathrm{ha}^{-1}, \mathrm{~T}_{3}=60 \mathrm{~kg} \mathrm{CD} \mathrm{N} \mathrm{ha}^{-1}, \mathrm{~T}_{4}=60 \mathrm{~kg} \mathrm{MOC} \mathrm{N} \mathrm{ha}^{-1}, \mathrm{~T}_{5}=30 \mathrm{~kg}$ Urea N ha ${ }^{-1}+30 \mathrm{~kg} \mathrm{CD} \mathrm{N} \mathrm{ha}^{-1}, \mathrm{~T}_{6}=30 \mathrm{~kg} \mathrm{Urea} \mathrm{N}$

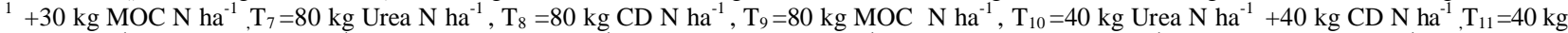

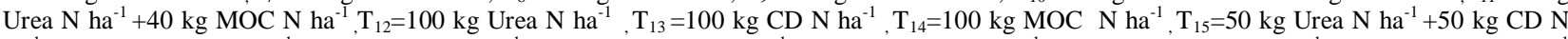
$\mathrm{ha}^{-1}, \mathrm{~T}_{16}=50 \mathrm{~kg}$ Urea N ha ${ }^{-1}+50 \mathrm{~kg} \mathrm{MOC} \mathrm{N} \mathrm{ha}^{-1}, \mathrm{~T}_{17}=120 \mathrm{~kg}^{2}$ Urea N ha ${ }^{-1}, \mathrm{~T}_{18}=120 \mathrm{~kg} \mathrm{CD} \mathrm{N} \mathrm{ha}^{-1}, \mathrm{~T}_{19}=120 \mathrm{~kg} \mathrm{MOC} \mathrm{N} \mathrm{ha}{ }^{-1}, \mathrm{~T}_{20}=60 \mathrm{~kg} \mathrm{Urea} \mathrm{N} \mathrm{ha}^{-1}$ $+60 \mathrm{~kg} \mathrm{CD} \mathrm{N} \mathrm{ha}^{-1}, \mathrm{~T}_{21}=60 \mathrm{~kg}$ Urea N ha $^{-1}+60 \mathrm{~kg} \mathrm{~N} \mathrm{ha}^{-1} \mathrm{MOC}$. 


\section{Plant height}

Plant height did not vary significantly due to varieties (Table 1) but it was varied significantly due to different sources and doses of nitrogen (Table 2). The highest plant height $(98.75 \mathrm{~cm})$ was observed in $120 \mathrm{~kg} \mathrm{~N}$ as Urea $\left(\mathrm{T}_{17}\right)$ which was statistically identical to $\mathrm{T}_{21}\left(60 \mathrm{~kg} \mathrm{~N}^{-1}\right.$ as urea $+60 \mathrm{~kg} \mathrm{~N} \mathrm{ha}^{-1}$ as MOC) and the lowest plant height $(81.04 \mathrm{~cm})$ was found in control treatment. Plant height is dependent on the number of internodes and their length. It represents the varietal characteristics of a variety. The differences in plant height of different varieties might have been resulted from genetic make up of the cultivars, but the environmental factors also influence a little. The results were in agreement with Shamsuddin et al. (1988) and BINA (1993). Increasing levels of nitrogen up to $120 \mathrm{~kg} \mathrm{~N} \mathrm{ha}^{-1}$ increased the plant height (Table 2). The increase in plant height due to application of increased level of nitrogen might be associated with stimulating effect of nitrogen levels on various physiological processes including cell division and cell elongation of the plant. These results are agreed with that of Kumar et al. (1995). Plant height did not show significant variation by the interaction of variety and nitrogen sources and doses (Table 3).

\section{Number of bearing tillers hill ${ }^{1}$}

Number of bearing tillers hill ${ }^{-1}$ differed significantly due to variety. BRRI dhan 28 and BRRI dhan36 produced higher (9.28) and lower (8.36) number of bearing tillers hill ${ }^{-1}$ respectively (Table 1 ). Number of bearing tillers hill ${ }^{-1}$ was significantly influenced by different doses and sources of nitrogen application. The maximum number of bearing tillers hill ${ }^{-1}$ (12.34) was found in the application of $60 \mathrm{~kg} \mathrm{~N} \mathrm{ha}^{-1}$ as Urea $+60 \mathrm{~kg} \mathrm{~N} \mathrm{ha}^{-1}$ as MOC $\left(\mathrm{T}_{21}\right)$ followed by $\mathrm{T}_{19}(120 \mathrm{~kg}$ $\mathrm{N} \mathrm{ha}^{-1}$ as MOC) and $\mathrm{T}_{16}\left(50 \mathrm{~kg} \mathrm{~N} \mathrm{ha}^{-1}\right.$ as Urea +50 $\mathrm{kg} \mathrm{N} \mathrm{ha}^{-1}$ as MOC) and the lowest number of bearing tillers hill ${ }^{-1}$ (5.45) was found in control (Table 2). The reasons for differences in producing bearing tillers hill $^{-1}$ might be due to the variation in genetic make-up of the variety that might be influenced by heredity. This was consistent with Chowdhury et al. (1993). The number of bearing tillers increased with the increase of nitrogen levels up to $120 \mathrm{~kg} \mathrm{~N} \mathrm{ha}^{-1}$ from all the sources. Variations in the number of bearing tillers among the different $\mathrm{N}$ sources were mainly due to their variations in the availability of $\mathrm{N}$ and other nutrients. Adequacy of nitrogen probably favored the cellular activities during panicle formation and development that led to increased number of bearing tillers hill ${ }^{-1}$. Gosh et al. (1991) also agreed to this view. The interaction effect of variety and nitrogen sources and doses were significant for number of bearing tillers hill ${ }^{-1}$. The interaction effect of BRRI dhan 28 with $60 \mathrm{~kg} \mathrm{~N} \mathrm{ha}^{-1}$ as Urea $+60 \mathrm{~kg} \mathrm{~N} \mathrm{ha}^{-1}$ as MOC $\left(\mathrm{V}_{1} \times \mathrm{T}_{21}\right)$ produced the highest number of bearing tillers hill ${ }^{-1}$ which was statistically identical to $\mathrm{V}_{1} \times \mathrm{T}_{19}$ but the lowest number of bearing tillers hill ${ }^{-1}$ was obtained from the interaction of $\mathrm{V}_{2} \times \mathrm{T}_{1}$ (Table 3 ).

\section{Non-bearing tillers hill ${ }^{1}$}

The results revealed that there was significant difference in number of non-bearing tillers hil $^{-1}$ between two rice varieties of obtaining 3.51 at BRRI dhan28 and 3.03 at BRRI dhan36 (Table 1). The number of non-bearing tillers $\mathrm{hil}^{-1}$ varied significantly due to different sources and doses of nitrogen (Table 2). It was observed that the highest non-bearing tillers hill $^{-1}$ (4.81) was found in the application of $120 \mathrm{~kg} \mathrm{~N} \mathrm{ha}^{-1}$ as Cowdung followed by $\mathrm{T}_{18}$ (100 kg N ha ${ }^{-1}$ as Cowdung) and the lowest 2.33 at control. There was no significant difference in the interaction effect of variety and sources and doses of nitrogen on number of non-bearing tillers hill ${ }^{-1}$ (Table 3 ).

\section{Panicle length}

Result showed the significant difference of panicle length between two varieties. BRRI dhan 28 produced higher panicle length of $22.84 \mathrm{~cm}$ and the lower panicle length $(20.47 \mathrm{~cm})$ was found in BRRI dhan 36 (Tables 1). Panicle length was also highly significant for different nitrogen sources and doses. The highest panicle length $24.68 \mathrm{~cm}$ was found in $\mathrm{T}_{19}(120 \mathrm{~kg} \mathrm{~N}$ $\mathrm{ha}^{-1}$ as MOC) and the lowest panicle length $(20.47 \mathrm{~cm})$ was found in control treatment (Table 2). The variation as assessed might be due to genetic characters of the varieties primarily influenced by the heredity. Diaz et al. (2000) also reported that panicle length varied among varieties. Results showed that panicle length increased with the increase of nitrogen rate. Nitrogen nutrient took part in panicle formation as well as elongation and for this panicle length increased with increase of $\mathrm{N}$-fertilization. Idris and Matin (1990) reported similar results. Panicle length was significantly influenced by the interaction between variety and sources and doses of nitrogen. The longest panicle was found in the combination of $\mathrm{V}_{1} \times \mathrm{T}_{21}$ (BRRI dhan 28 with $60 \mathrm{~kg} \mathrm{~N} \mathrm{ha}^{-1}$ as Urea +60 $\mathrm{kg} \mathrm{N} \mathrm{ha}{ }^{-1}$ as MOC) but the shortest panicle was produced in $\mathrm{V}_{1} \times \mathrm{T}_{1}$ combination (BRRI dhan 28 with control treatment) (Table 3). 


\section{Number of grains panicle ${ }^{-1}$}

Number of grains panicle ${ }^{-1}$ was significantly influenced by the variety. The highest number of grains panicle ${ }^{-1}$ (115.00) were observed in BRRI dhan28 and the lowest number of grains panicle ${ }^{-1}$ (111.00) was found in BRRI dhan36 (Tables 1). There was a marked influence on number of grains panicle ${ }^{-1}$ by different levels and sources of nitrogen. The highest number of grains panicle $^{-1}$ (142.27) was observed in $100 \mathrm{~kg} \mathrm{~N} \mathrm{ha}^{-1}$ as MOC $\left(\mathrm{T}_{14}\right)$ followed by $\mathrm{T}_{19}$ and the lowest (86.11) was in control (Table 2). Varietal variation regarding the number of filled grains panicle ${ }^{-1}$ might be due to their variation in genetic constitutions and also due to variation in photosynthetic assimilate accumulation especially after heading. Moula (2002) reported variable number filled grains panicle ${ }^{-1}$. Adequate supply of nitrogen contributed to grain formation, which probably increased number of grains panicle ${ }^{-1}$ with increasing nitrogen level. The present results explicitly confirm the similar results obtained by Chander and Pandey (1996) who recorded the highest number of grains panicle ${ }^{-1}$ at $120 \mathrm{~kg} \mathrm{~N} \mathrm{ha}^{-1}$. Bhuiya et al. (1989) also recorded the positive influence of nitrogen level on the production of number of grains panicle $^{-1}$. Significant influence was found on the number of grains panicle ${ }^{-1}$ due to the interaction effects between variety and sources and doses of nitrogen. The highest number of grains panicle ${ }^{-1}$ was found in the interaction of $\mathrm{V}_{1} \times \mathrm{T}_{14}$ (BRRI dhan 28 with $100 \mathrm{~kg} \mathrm{~N} \mathrm{ha}^{-1}$ as MOC) but the lowest number of grains panicle ${ }^{-1}$ was produced in $\mathrm{V}_{2} \times \mathrm{T}_{1}$ combination (BRRI dhan36 with control treatment) (Table 3).

\section{Sterile spiklets panicle $e^{-1}$}

The number of sterile spikelets panicle ${ }^{-1}$ varied significantly between two varieties. The highest sterile spikelets panicle ${ }^{-1} 13.48$ was found in BRRI dhan 36 and the lowest 12.35 was obtained from BRRI dhan28 (Table 1). This variation might be due to genetic characteristics of the varieties. Nitrogen sources and doses were highly significant for sterile spikelets panicle $^{-1}$. Among the nitrogen sources and doses, it was the highest (15.40) at $120 \mathrm{~kg} \mathrm{~N} \mathrm{ha}^{-1}$ as cow dung $\left(\mathrm{T}_{18}\right)$ followed by $\mathrm{T}_{20}\left(60 \mathrm{~kg} \mathrm{~N} \mathrm{ha}^{-1}\right.$ as Urea $+60 \mathrm{~kg} \mathrm{~N}$ $\mathrm{ha}^{-1}$ as cow dung) and the lowest (9.10) was found at $\mathrm{T}_{9}$ (80 kg N ha ${ }^{-1}$ as MOC (Table 2). Among the nitrogen sources, the maximum number of sterile spikelets panicle ${ }^{-1}$ was found in $120 \mathrm{~kg} \mathrm{~N} \mathrm{ha}^{-1}$ as cow dung $\left(\mathrm{T}_{18}\right)$ and the lowest one was obtained from $80 \mathrm{~kg}$ $\mathrm{N} \mathrm{ha}^{-1}$ from MOC $\left(\mathrm{T}_{9}\right)$. Similar result was found by BRRI (1985) who reported that the application of only cow dung as a nitrogen source increased the sterility percentage $(22 \%)$ over control $(13 \%)$. The number of sterile spikelets panicle ${ }^{-1}$ varied significantly between the interaction effect of variety and sources and doses of nitrogen. The highest number of sterile spikelets panicle $^{-1}$ was found in the combination of $\mathrm{V}_{2} \times \mathrm{T}_{3}$ ((BRRI dhan36 with $60 \mathrm{~kg} \mathrm{~N} \mathrm{ha}^{-1}$ as MOC) (Table 3).

\section{Thousand grain weight}

There was no significant variation for weight of 1000- grain in two rice varieties (Table 1). Application of different sources and doses nitrogen showed significant effect on 1000-grain weight. The highest 1000 -grain weight $24.50 \mathrm{~g}$ was found in $\mathrm{T}_{19}$ $\left(120 \mathrm{Kg} \mathrm{N} \mathrm{ha}^{-1}\right.$ as MOC) followed by $\mathrm{T}_{14}(100 \mathrm{Kg} \mathrm{N}$ $\mathrm{ha}^{-1}$ as MOC) and the lowest 1000 grain weight $\left(22.08 \mathrm{~g}\right.$ ) was observed in $\mathrm{T}_{2}\left(60 \mathrm{Kg} \mathrm{N} \mathrm{ha}^{-1}\right)$ (Table 2). The variation in 1000-grain weight might be due to differences of length and breath of the grains that were partly controlled by genetic makeup of the variety under study. Chowdhury and Ghosh (1978) stated that 1000-grain weight highly varied due to variety ranged from $9.00 \mathrm{~g}$ to $23.00 \mathrm{~g}$ fine and scented rice varieties. The interaction effect due to variety and sources and doses of nitrogen did not affect the 1000-grain weight significantly (Table 3 ).

\section{Grain yield}

Varieties under study showed significant variation in grain yield. BRRI dhan 28 produced higher grain yield $4.62 \mathrm{t} \mathrm{ha}^{-1}$ and BRRI dhan36 produced lower $4.34 \mathrm{t}$ ha $^{-1}$ (Table 1$)$. Not only the number of effective tillers hill $^{-1}$, length of panicle, number of filled grains panicle $^{-1}, 1000$ grain weight were maximum which probably caused the highest grain yield. The yield of rice mainly depends on the yield contributing characters like the number of effective tillers hill ${ }^{-1}$, number of grains panicle ${ }^{-1}$, weight of individual grain or thousand grains weight and number of spikelet sterility. Physiological parameters also play an important role on rice yield, which was supported by Cui-Jing et al. (2000). They obtained that higher rice yield possible by increasing total dry matter and harvest index. Grain yield differences due to varieties were also reported by Biswas et al. (1998). Results showed that there was a marked influence on grain yield by the application of different sources and doses of nitrogen. The highest grain yield $\left(5.85 \mathrm{tha}^{-1}\right)$ was observed in $\mathrm{T}_{21}\left(60 \mathrm{~kg} \mathrm{~N}^{-1}\right.$ as Urea $+60 \mathrm{~kg} \mathrm{~N}^{-1}$ as MOC) which was statistically similar to $T_{16}(50 \mathrm{~kg}$ $\mathrm{N} \mathrm{ha}^{-1}$ as Urea $+50 \mathrm{~kg} \mathrm{~N} \mathrm{ha}^{-1}$ as MOC) and $\mathrm{T}_{19}(120$ $\mathrm{kg} \mathrm{N} \mathrm{ha}^{-1}$ as MOC) but the lowest grain yield $(2.51 \mathrm{t}$ $\mathrm{ha}^{-1}$ ) was obtained from no nitrogen (Control) application (Table 2). Results revealed that a combination of organic and inorganic $\mathrm{N}$ sources 
resulted in comparable better rice yields. The grain yield progressively increased with the increase of organic manure. It might be due to the presence of organic manure that enhanced the effectiveness of chemical fertilizer. Liu et al. (1990) stated that the use of organic fertilizers in addition to chemical fertilizer increased soil OM and total $\mathrm{N}$, increased the effectiveness of soil $\mathrm{P}$. The increase in yield might be due to the contribution of more number of effective tillers hill ${ }^{-1}$, panicle length, number of grains panicle ${ }^{-1}$ and 1000 grain weight. Balasubramaniyan (1984) reported that number of tillers hill ${ }^{-1}$, number of grains panicle $^{-1}$ and 1000-grain weight and ultimately the grain yield per unit area increased with increasing nitrogen application up to a range of $80 \mathrm{~kg}$ to $120 \mathrm{~kg}$ $\mathrm{N}$ ha ${ }^{-1}$. Similar trend was also observed by Karmakar and Ali (2006) and Islam et al. (2007a and b). Grain yield was insignificant due to the interaction between variety and sources and doses of nitrogen (Table 3).

\section{Straw yield}

Straw yield varied significantly due to variety. BRRI dhan 28 and BRRIdhan 36 produced higher $(5.25 \mathrm{t} \mathrm{ha}$ $\left.{ }^{1}\right)$ and lower (4.93 $\left.\mathrm{t} \mathrm{ha}^{-1}\right)$ straw yield respectively (Table 1). Straw yield varied significantly by the application of different sources and levels of nitrogen. The highest straw yield $\left(6.34 \mathrm{tha}^{-1}\right)$ was observed in $\mathrm{T}_{21}\left(60 \mathrm{~kg} \mathrm{~N} \mathrm{ha}^{-1}\right.$ as Urea $+60 \mathrm{~kg} \mathrm{~N} \mathrm{ha}^{-1}$ as MOC) followed by $\mathrm{T}_{19}\left(120 \mathrm{~kg} \mathrm{~N} \mathrm{ha}^{-1}\right.$ as MOC) and the lowest straw yield $\left(3.48 \mathrm{t} \mathrm{ha}^{-1}\right)$ was obtained from control (Table 2). The reasons for higher straw yield in the variety of BRRI dhan 28 was due to its higher plant height and total tillers hill ${ }^{-1}$ i.e. the combined effect of plant height and tiller number. This result was supported by Chandra et al. (1992) who reported difference straw yield among varieties. Straw yield increased with the increase of $\mathrm{N}$ levels. Similar results were found by Karmakar and Ali (2006) and Islam et al. (2007a and b). Straw yield varied significantly due to the interaction of variety and sources and doses of nitrogen. The interaction effect of BRRI dhan28 with $60 \mathrm{~kg} \mathrm{~N}^{-1}$ as Urea $+60 \mathrm{~kg} \mathrm{~N}$ $\mathrm{ha}^{-1}$ as MOC $\left(\mathrm{V}_{1} \times \mathrm{T}_{21}\right)$ gave the highest straw yield which was statistically identical to $\mathrm{V}_{1} \times \mathrm{T}_{20}$ but the lowest straw yield was obtained from the interaction of $\mathrm{V}_{2} \times \mathrm{T}_{1}$ (Table 3).

\section{Harvest index}

Harvest index did not vary due to varieties but varied significantly by the application of different sources and doses of nitrogen (Tables 1 and 2). The highest harvest index $48.68 \%$ was found in $\mathrm{T}_{14}\left(100 \mathrm{~kg} \mathrm{~N} \mathrm{ha}^{-1}\right.$ as MOC) followed by $\mathrm{T}_{16}\left(50 \mathrm{~kg} \mathrm{~N} \mathrm{ha}^{-1}\right.$ as urea +50 $\mathrm{kg} \mathrm{N} \mathrm{ha}^{-1}$ as MOC) and $\mathrm{T}_{19}\left(120 \mathrm{~kg} \mathrm{~N} \mathrm{ha}^{-1}\right.$ as MOC). The lowest harvest index $(41.90 \%)$ was found in control. Insignificant influence was observed on $\mathrm{HI}$ due to the interaction effect of variety and sources and doses of nitrogen (Table 3).

\section{Conclusions}

For improvement and sustenance of rice productivity, integrated use of synthetic $\mathrm{N}$ and organic $\mathrm{N}$ sources is needed to be practiced. Besides the conventional sources of organic N like FYM and green manure, non-conventional sources like mustard oil cake can be used in rice field as a good source of organic N. Based upon the findings of the study following conclusions can be drawn:

BRRI dhan 28 produced higher yields than BRRI dhan36. In general, organic manures alone could not produce higher grain yield but the combination of organic and inorganic fertilizers produced higher yield. The application of $60 \mathrm{~kg} \mathrm{~N}^{-1}$ as urea with 60 $\mathrm{kg} \mathrm{N} \mathrm{ha}^{-1}$ as mustard oil cake produced the highest grain and straw yields which were statistically identical to the yield of $50 \mathrm{~kg} \mathrm{~N} \mathrm{ha}^{-1}$ as urea with 50 $\mathrm{kg} \mathrm{N} \mathrm{ha}^{-1}$ as mustard oil cake. It was further observed that replacement of $50 \%$ urea N by MOC was the best source of nitrogen considering higher yield of boro rice.

\section{References}

AIS (Agriculture Information Service). 2007. Krishi Diary. Agric. info. Service, Khamarbari, Dhaka. $53 \mathrm{p}$.

AIS (Agriculture Information Service). 2008. Krishi Diary. Agric. info. Service, Khamarbari, Dhaka. $66 \mathrm{p}$.

Bair, W. 1990. Characterization of the environment for sustainable agriculture in Semi-arid Tropics. In: Proc. Sustainable Agriculture Issue, Prospective and Prospects in Semi-arid Tropics (ed. Singh, R.P.), Hydderabad, India. India Soc. Agron. pp. 90-128.

Balasubramaniyan, P. 1984. Nitrogen fertilization for short duration rice. Intl. Rice Res. Newsl., Manila, Philippines. 9(5):29.

BBS. 2004. Monthly Statistical Bulletin of Bangladesh Bureau of Statistics, Statistics Division, Min. Plan. Govt. Peoples Repb. Bangladesh, Dhaka. pp. 54-58. 
Bhuiya, M.S.U.; Hossain, S.M.A.; and Kabir, S.K.G. 1989. Nitrogen fertilization in rice cv. BR10 after green munaring. Bangladesh J. Agril. Sci. 16(1): 89-92.

Bhuiyan, N.I. 1994. Crop production trends and need of sustainability in agriculture. The paper presented at the workshop on Integrated Nutrient Management for sustainable Agriculture, held at SRDI, Pabna, Bangladesh. June 26-28.

BINA (Bangladesh Institute of Nuclear Agriculture). 1993. Annual Report for 1992-93, Bangladesh Inst. Nuclear Agric., P.O. Box No. 4. Mymensingh. 143p.

Biswas, J.W.; Hossain , M.A.; Sarker, B.C.; Hansan, M. and Haque, M.Z. 1998. Yield performance of several rice varieties seeded directly as late aman crops. Bangladesh J. Life Sci. 10(1\&2): 47-52.

BRRI (Bangladesh Rice Research Institute). 1985a. Annual report for 1981. BRRI Pub. No. 71. Joydebpur, Gazipur, Bangladesh. pp.2-8.

BRRI (Bangladesh Rice Research Institute). 1985 b. Annual report for 1982. BRRI Pub. No. 73. Joydebpur, Gazipur, Bangladesh. pp.4-220.

Chander, S. and J. Pandey. 1996. Effect of herbicide and nitrogen on yield of scented rice (Oryza sativa) under different rice cultures. Indian $J$. Agron. 41(2):209-214.

Chandra, B.V.; Mahadevappa, M.; Krishnmurthy, A.H. and Bhaskar, V. 1992. Performance of BRRI rice hybrid in Mandya, Karnataka, India. Intl. Rice Res. Newsl. 17(2):6.

Chowdhury, M.J.U.; Sarker, A.U.; Sarker, M.A.R. and Kashem, M.A. 1993. Effect of variety and number of seedlings hill ${ }^{-1}$ on the yield and its components on late transplanted aman rice. Bangladesh J. Agril. Sci. 20 (2): 311-316.

Chowdhury, D. and Ghosh, A.K. 1978. Evaluation of agronomic and physiological characters of fine and scented rice varieties. Indian J. Agril. Sci. 48(10): 373-37.

Cui-jing, Kusutani, A.; Toyata, M.; Asunuma, K. and Cui, J. 2000. Studies on the varietals differences of harvest index and morphological characteristics of rice. Japanese J. Crop Sci. 69(3): 359-364.

Diaz, S.H.; Castro, R. and Morejon, R. 2000. Morpho-agronomic characterization of varieties of rice. Instituto Nacional de ciencias Agricolas, Gaveta Postall, San Jose, de las, Lajsa, La Habna, Cuba, 21(3): 81-86.

De Datta, S.K.; Stangel. P.J. and Cras well, E.T. 1981. Evaluation of nitrogen fertility and increasing fertilizer efficiency in wet lands rice soils. Proc. Symp. on paddy. Soil Sci. Press. Beejing. China. pp. 171-206.
FAO (Food Agriculture Organization). 1999. FAO Indices of Food and Agricultural Production. Food Agric. Org., Rome, Italy. pp.18-19.

Ghosh, B.C.; C.V. Raghavaian and M.K. Jana. 1991. Effect of seedrate and nitrogen on growth and yield of direct sown rice (Oryza sativa L.) under intermediate deep water condition. Indian $J$. Agron. 36: 227-228.

Gomez, K.A. and Gomez., A.A. 1984. Statistical Procedure for Agricultural Research, $2^{\text {nd }}$ Ed. John Willey and Sons. New York, Chichester, Brisbane, Toronto, Singapore. 680p.

Hossain, S.M.A., and Islam, M. S. 1986. Fertilizer Management in Bangladesh. Adv. Agron. Res. Bangladesh Soc. Agron. pp. 48-54.

Hossain, S.M.A.; Satter, M. and Ahmed, J.U. 1981. Bench Mark Survey. Kanhar Cropping System Research Site. Graduate Training Institute and Department of Agronomy. Bangladesh Agricultural University. Mymensingh.

Islam, M.A. 1989. A study on public Oriented Cropping Patterns under Rainfed and Irrigated Conditions. Ph. D. Thesis. Dept. Agron. Bangladesh Agril. Univ., Mymensingh. 172p.

Idris, M. and Matin, M.A. 1990. Response of four exotic stains of aman rice to urea. Bangladesh J. Agril. Sci. 17(2): 271-275.

Islam, M.M.; Anwar, M.P.; Rahman, M.M. and Islam A.K. M.M. 2007a. Influence of mustard oil cake on the performance of fine rice cv. chinigura. Intl. J. BioRes. 3(6): 50-54.

Islam, M.M.; Anwar, M.P.; Rahman, M.M. and Islam A.K. M.M. 2007b. Influence of mustard oil cake on the performance of fine rice cv. chinigura. Intl. J. BioRes. 3(6): 50-54.

Karmakar, B. and Ali, B.A. 2006. Effect of mustard oil cake and other organic fertilizers on the performance of boro rice. Annual Internal Review, 2005-2006. Bangladesh Rice Res. Inst., Joydebpur, Gazipur. pp. 26-28.

Kumar, G.H.; Reddy S.N. and Ikramullah M. 1995. Effect of age of seedling and nitrogen doses on the performance of rice (Oryza sativa) under late planting. Indian J. Agric. Sci. 6595: 354-355.

Liu, J, R.; Zhang, D.Y. and Zhou, W. 1990. The effect of mixed application of organic and inorganic fertilizers to paddy soil (third report). Acta Agriculturae Universities Jiangxiensis. 12(1):37-42.

Moula, M.G. 2002. A study on relationship between physiological parameters and grain growth of boro rice. M.S. Thesis, Bangladesh Agricultural University, Mymensingh. 107p.

Sarvanan, A.; Velu V. and Ramanath, K.M. 1987. Effect of combined application of bioorganic and chemical fertilizers on physical properties, 
nitrogen transformation and yield of rice in submerged soils. Oryza: 1-6.

Sharma, A.R. and Mitra, B.N. 1991. 1991. Direct and residual effect of organic material and phosphorous fertilizers in rice (Oryza sativa L.) based cropping System. Indian J. Agron. 36(3): 299-303.

Shamsuddin, A.M.; Islam, M.A. and Hossain, A. 1988. Comparative study on the yield and agronomic characters of nine cultivars of aus rice. Bangladesh J. Agril. Sci. 15(1): 121-124. 